DOI: $10.13037 /$ ci.vol21n45.6168

\title{
Caminhos da cena de música eletrônica em festas de rua em SP: estéticas, territórios e ativismos na festa e no personagem CARLOS CAPSLOCK ${ }^{1}$
}

\section{PATHS OF THE ELECTRONIC MUSIC SCENE AT STREET PARTIES IN SP: AESTHETICS, TERRITORIES AND ACTIVISM IN THE PARTY AND THE CHARACTER CARLOS

\section{Simone Luci Pereira ${ }^{1}$}

ORCID: https://orcid.org/0000-0002-7412-2129

(Universidade Paulista, Programa de Pós-Graduação de Comunicação e Cultura Midiática. São Paulo - SP, Brasil)

\section{Oziel Gheirart ${ }^{2}$}

ORCID: https://orcid.org/0000-0002-6035-9248

(Universidade Paulista, URBESOM - Programa de Pós-Graduação de Comunicação e Cultura Midiática. São Paulo - SP, Brasil)

Recebido em 19/07/2019. Aprovado em 30/09/2019.

\section{Resumo}

Este artigo analisa a recente cena de música eletrônica em São Paulo, que migrou dos clubes para as festas de ruas. Estas possuem forte viés político ressaltando os usos dos espaços urbanos, os direitos LGBTQI+, as corporalidades e estetizações juvenis. Focamos aqui o personagem e a festa Carlos CapsLock, que existe desde 2010 e salienta alguns aspectos históricos e mais recentes desta cena paulistana. Por meio de trabalho de campo de inspiração etnográfica e análise da fanpage da festa, atentamos para as dinâmicas desta cena e seus caminhos atuais bifurcados e abertos.

Palavras-chave: Cultura urbana. Ativismo juvenil. Cena da música eletrônica.

\section{Abstract}

This article analyzes the recent scene of electronic music in São Paulo, that migrated from the clubs to the street parties. These have a strong political dimension emphasizing the uses of urban spaces, LGBTQI + rights, corporalities and youth aesthetics. We focus here on the character and the party Carlos CapsLock, which has existed since 2010 and highlights some historical and more recent aspects of this scene in São Paulo. Through fieldwork with ethnographic inspiration and analysis of the CapsLock fanpage, we look at the dynamics of this scene and its bifurcated and open paths.

Keywords: Urban culture. Youth activism. Electronic music scene

${ }^{1}$ Uma primeira versão deste artigo foi aprovada para apresentação no GP Comunicação e Culturas Urbanas, dentro do $42^{\circ}$ Congresso Brasileiro de Ciências da Comunicação - Intercom 2019. 


\section{Introdução}

Este artigo apresenta alguns desdobramentos de pesquisa em andamento a respeito dos coletivos juvenis organizadores/produtores de festas de música eletrônica de pista, que surgiram em São Paulo a partir de 2010 e se mantêm atuantes até os dias de hoje (PEREIRA; GHEIRART, 2018). Interessa-nos acompanhar esta dinâmica da cena da música eletrônica em São Paulo, que migrou dos clubes para as ruas e teve como elemento fundante as festas que ressaltam os usos dos espaços urbanos, os direitos LGBTQI+, corporalidades e estetizações juvenis com forte viés político. As festas e as atividades dos coletivos evidenciam a centralidade da música e sua dimensão comunicacional nos meios urbanos (PEREIRA, 2017), reunindo pessoas para dançar, performatizar e visibilizar identidades, construir vinculações e ativismos (FERNANDES; HERSCHMANN, 2015), formas de estar juntos, usar a cidade e ocupá-la sonora, social e culturalmente.

Nessa cena/circuito, destacam-se alguns protagonistas que compuseram uma linha de frente e, dentre eles, destacamos neste artigo Paulo Tessuto (e seu personagem Carlos CapsLock): paulistano de 31 anos que viveu a cena da música eletrônica paulistana dos anos 1990 e tem atuação nestas dinâmicas atuais que pesquisamos. Nos primeiros anos da década de 2000, estreou como DJ e nos anos seguintes se estabeleceu nos grandes clubes da cidade. Por conta da indignação do artista com relação à falta de criatividade, homogeneização e elitização que, segundo ele, se instituiu na cena, se envolveu com o coletivo internacional Voodoohop ${ }^{1}$, laboratório a partir do qual articulou e estruturou ações e intervenções artísticas e políticas. Em 2010, nascia o personagem Carlos CapsLock, mistura de DJ, viral e performer e a primeira festa de música eletrônica (de mesmo nome do personagem), com ênfase no house e no tecno, construindo novos modelos no que tange aos posicionamentos político-sociais, estilos/estéticas e tomada das ruas. Com o intuito de revitalizar a cena musical e cultural, o artista (DJ, produtor, performer, artista gráfico) passou a produzir "multiartes", na qual usa, segundo ele, o corpo como mídia para circular questionamentos e apresentar uma sonoridade tecno-punk misturada ao tecno berlinense, microhouse e samplers.

O objetivo deste artigo - na busca por compreender percursos, nuances e aspectos desta cena recente de música eletrônica nas ruas de SP - é analisar o personagem e a festa CapsLock, que existe e sobrevive desde 2010 e tem sido um modelo para outras festas

\footnotetext{
${ }^{1}$ Segundo o site do grupo, Voodoohop é um coletivo internacional de arte nascido de uma série de festas underground. Em 10 anos de eventos colaborativos, reuniu uma miríade de artistas de diferentes áreas - como DJs, artistas ao vivo, dançarinos e artistas visuais. Disponível em: https://voodoohop.com/ Acesso em: 20/01/2019.
} 
na cidade. A escolha da CapsLock se dá porque a festa foi precursora desse movimento e das mudanças que aconteceram na noite de São Paulo, fazendo com que sua própria história nos apresente elementos para analisar este processo mais amplo das dinâmicas da cena analisada, em suas resistências, incorporações e negociações com lógicas mais hegemônicas. A CapsLock nos ajuda a perceber alguns dos caminhos tomados por esta cena, os quais não são únicos e revelam diferenciações, controvérsias, conflitos, pontos de estabilização (LATOUR, 2012) dentro desta rede maior de coletivos juvenis envolvidos nesta cena musical. A metodologia usada se baseia em: 1) trabalho de campo de inspiração etnográfica (observação direta e utilização de diário de campo nas festas, com atenção aos seus aspectos imagéticos, musicais, sonoros, estéticos, interacionais); 2) entrevistas com DJs, produtores e público; 3) análise dos materiais de divulgação em flyers e na fanpage do Facebook ${ }^{2}$ em seus elementos imagéticos e textuais.

Iniciamos o artigo trazendo alguns apontamentos sobre esta cena recente das festas de música eletrônica de pista feitas por coletivos juvenis nas ruas, ressaltando algumas de suas características gerais, bem como refletindo sobre questões do espaço, território e poder que ali se esboçam. Em seguida, analisamos o personagem e a festa CapsLock, sublinhando a trajetória de Paulo Tessuto, da festa, da "montação" e os textos publicados em flyers e na fanpage em suas dimensões estéticas e performativas. Ao final, buscamos apresentar algumas conclusões parciais que nos revelam a pluralidade de caminhos abertos por esta cena e a diversidade de encaminhamentos que daí podem vir no futuro, bem como suas dimensões políticas. Atentamos para a dinâmica, fluidez e certa rapidez que movem estas ações, tanto pelas próprias lógicas de produção e consumo cultural na cidade, como pelas mudanças na política institucional e macroestrutural que estamos vivendo na cidade e no país. Lembramos ainda que estas mudanças constantes se mostram como lógica das próprias culturas juvenis e urbanas, as quais apresentam elementos emergentes que logo podem se tornar dominantes e/ou residuais (WILLIAMS, 1979), suas múltiplas associações e criação de redes, exigindo das pesquisas uma atenção às nuances, aos elementos incidentais, fragmentários e contraditórios, sem buscar sínteses explicativas, mas sim mapeando as controvérsias (LATOUR, 2012) aí presentes.

\section{Uma recente cena paulistana}

Desde os anos 1990, Straw (2013) chama de cena musical determinados conjuntos de atividades sociais e culturais mais ou menos organizados, que nos convidam a refletir

$\underline{2}$ https://www.facebook.com/carloscapslock/ 
sobre as culturas urbanas a partir de novas maneiras de conceber os territórios da cidade. Estes são constituídos em torno da música, das sonoridades, da dança, dos estilos, das modas, das estéticas, dos gostos e das identidades, podendo ser organizados segundo gêneros musicais ou segundo as atividades sociais ali desenvolvidas, ajudando a construir lógicas de produção e consumo material e cultural, bem como a própria cidade e a vida urbana. Esta noção de cena musical/cultural nos ajuda a compreender questões, aspectos e lógicas desta movimentação dos coletivos juvenis ligados à música eletrônica e suas festas nas ruas e em outros espaços de São Paulo nesta última década.

Já narramos anteriormente (PEREIRA; GHEIRART, 2018) nossa experiência de frequentar e nos inserirmos nesses espaços materiais e simbólicos das festas $(O D D$, Vampire Hauss, Mamba Negra, Caldo, BLUM, Síntese Coletiva, Chorume, Düsk, Carlos CapsLock, Gop Tun, entre outras) nas ruas e praças, em galpões e prédios próximos à região central, e também nos eventos organizados pela prefeitura de São Paulo (como o SP Música, dedicado à música eletrônica). Percebemos diversos formatos e práticas conjugadas nos eventos, tais como: a presença e centralidade dos DJs, live acts, festivais agregados com performances e intervenções visuais.

No início da investigação fizemos contato com diversas pessoas relacionadas às festas, o que nos permitiu chegar num primeiro grupo com três festas: 1) Mamba Negra (um coletivo feminista que atua em várias pautas do debate público, que possui uma label e tem destaque internacional); 2) Autônoma-atemporária (a festa foi um braço da VoodooHop e tem um aporte nômade de reinvenção da experiência no espaço urbano, tendo a música com centro das suas ações (o nome faz alusão às zonas autônomas temporárias de Hakin Bey, 2001); 3) Síntense Coletiva (a qual reúne músicos, estudantes e interessados em música; oferece cursos e consertos de instrumentos e promove festivais e escambos de equipamentos).

A partir deste recorte buscamos compreender as festas produzidas, tendo em vista as sonoridades ali presentes, as atividades de produção musical e produção dos eventos (formas de organização, produção, divulgação etc.). Ao mesmo tempo, também quisemos compreender as atividades "extra festa" realizadas por esses coletivos, como cursos, oficinas, encontros, festivais etc. Na nossa análise, observamos que esta nova cena traz como características um centralidade da música - pista, produção, circulação, conexão, experiência sensória - e nas práticas musicais - DJs, músicos, produtores, liveperformers, artistas visuais, técnicos de som, promoters; a recuperação de uma atitude underground (que segundo os atores havia se perdido) expressa nos comportamentos, 
na estetização e nos engajamentos, construindo práticas musicais-midiáticas alternativas/ autorais com funções estéticas, sociais e políticas.

As ações dos coletivos analisados salientam os sentidos políticos de tais práticas lúdicas e festivas, tanto por estarem articuladas a grupos e minorias discriminadas e pouco representadas na cena eletrônica, como trans ou pretxs (no caso da Mamba Negra); pelas formas mais autogestionárias, colaborativas e horizontais de produzir e divulgar a música eletrônica (enfatizadas pelo Sintese Coletiva); como também nas maneiras de pensar e usar os espaços públicos de São Paulo, os ocos da cidade esvaziados pelo medo urbano e pelas lógicas econômicas que valorizam os locais fechados, higienizados e controlados (no caso do coletivo $A$-Temp).

Neste contexto, vão se desenhando no cotidiano destes grupos avanços, recuos, seduções e resistências em caminhos não previamente planejados, reinventando o fazer político na pluralidade e na ampliação do acesso à vida urbana e na ocupação dos espaços fraturados e esquecidos da cidade. Elaboram-se formas de atuação, organização, produção e acontecimento dessas festas de rua, em que todos (seja quem produz, organiza, toca ou dança) são participantes de um mesmo projeto e ideário, fazendo daquele momento uma brecha na rotina dos espaços centrais da cidade, ocupados por outros usos e transformados em territórios alternativos (HAESBAERT, 2002) por ações momentâneas e moleculares. A dimensão espacial (MASSEY, 2005) mostra aí sua importância e potência, na medida em que torna possível a possibilidade da diferença e da pluralidade.

Percebemos também elementos os quais Foucault (2015) chamou de espaços heterotópicos ou heterotopias. Segundo o autor, as heterotopias não se confundem com utopias (lugares inexistentes ou inalcançáveis), mas configuram espaços outros que suspendem, neutralizam ou invertem o conjunto de relações por eles designadas. Nestes espaços, que podem ser mais ou menos temporários, localizam-se as lógicas das heterotopias, como lugares de suspensão do tempo e do espaço regrados e prédeterminados, fazendo de sua fruição e uso algo que remete à contestação e à inversão. Nas festas analisadas, práticas microbianas, micropolíticas, sub-reptícias se constroem entre o uso institucional do espaço (regrado, com horários, proibições, segregações etc.) e o espaço apropriado, ressignificado, subvertido, usado para atualizar e problematizar forças, poderes, sentidos.

Em campo, no período de um ano, nos aproximamos de coletivos que possibilitassem uma observação ampla e diversa para cartografar (FERNANDES e HERSCHMANN, 2015) e analisar esse fenômeno urbano. Importante ressaltar que a música eletrônica 
surge aqui como elo integrador, elemento comunicacional central destes eventos e das atividades e preocupações dos coletivos, desdobrando-se em muitos tentáculos, tais como o ativismo político em várias causas, o questionamento e ocupação dos espaços da cidade, bem como visualidades, estetizações e corporalidades ali acionadas e performatizadas. Ranciére (2009) nos ajuda a compreender a questão estética articulada à dimensão política, uma vez que nestes eventos narrados, as partilhas do sensível se fazem presentes ao criar vínculos e ajudar a compor novas subjetividades políticas coletivas. Experiências festivas que se mostram políticas e sensíveis, ligadas às vivências do "ser em comum" e atuando nas formas de emancipação, visibilidade e competência narrativa e de posicionamento sociocultural e identitário. Tem-se assim o papel das expressões artísticas e das estetizações em geral como ingrediente político de intervenção, de ocupação nas cidades, formação de pertencimentos pelos encontros de disposições, gostos e interesses comuns que forjam partilhas sensíveis como também dissensos ao desafiar e fazer usos inauditos de territórios da cidade desafinando um coro hegemônico do discurso da ordem pública que se quer harmônico e sem conflitos.

As cidades vêm revelando cada vez mais sua face comunicacional. Compreender a vida e as dinâmicas urbanas na atualidade implica em interpretar os territórios perpassados pelos fluxos de comunicação e informação. Comunicação pensada como processo de trocas materiais e simbólicas, (des)encontros, dinâmicas de interculturalidade e negociação sociocultural, expressando e construindo as relações entre os atores. Temos como objetivo compreender as múltiplas formas e configurações da comunicação urbana e o papel das práticas musicais/artísticas nas formas do viver nas cidades.

Uma certa movimentação com dimensões globais e locais trouxe à pauta a ocupação dos espaços urbanos, seu uso e o direito a ele. Em São Paulo, isso tem sido visível na última década (tanto por ações de coletivos ligados à questão urbana, quanto por pautas governamentais) e se tornado explícito no uso de praças e ruas em eventos oficiais ou não e na expansão do Carnaval de rua dos últimos anos, o qual vem dando grande espaço para a música eletrônica - chegando a reunir mais de 2 mil pessoas em uma festa. Reia, Herschmann e Fernandes (2018, p. 12-13), em pesquisa sobre música de rua no Rio de Janeiro, lembram que a ocupação não é apenas espacial, mas também sonora, social e cultural, uma vez que a música "transmite mensagem, sua interação transforma o espaço, interage com os sentidos, conecta as pessoas com o ambiente. [...] Só o fato de ocupar espaços públicos que não foram originalmente desenhados para este fim, já a torna um ato político". 
$\mathrm{O}$ aumento dessa demanda pelo uso das ruas trouxe alguns enfrentamentos. As mudanças políticas na gestão da cidade de São Paulo desde 2017 vêm resultando num desgaste que tem desestabilizado os coletivos e culminaram numa grande turbulência, travando uma disputa entre o poder público e esses jovens atores. Podemos elencar como principais motivos: a) os processos para conseguir alvarás de uso do espaço público se burocratizaram ainda mais - o que obrigou os coletivos a investirem em locações; $b$ ) os modelos gestionários que se constituíram em campo implicaram em instabilidade financeira e logística; c) a pulverização do grande público com o aparecimento de muitas festas no mesmo modelo causou certo esvaziamento dos eventos; d) os interesses dos grandes empresários do mercado de entretenimento fazendo pressão, não incluindo as festas em suas demandas e buscando cooptar ideias e artistas.

Os coletivos - especialmente aqueles que não tinham fins lucrativos - foram obrigados a pensar em novas táticas, já que a demanda da população paulistana de ocupar a cidade foi se solidificando. Com a pouca quantidade de alvarás liberados e que ainda limitavam os horários dos eventos até às $21 \mathrm{~h}$, as festas tiveram que usar galpões e locações improvisadas e dependentes de uma estrutura maior, o que acarretou numa certa padronização e elitização dos eventos. Hoje são poucas as festas que acontecem na rua, fora dos eventos controlados pela prefeitura - Dia Municipal da Música Eletrônica, criado pela deputada Soninha Francine; MIC (Mês Independente da Cultura); e a Virada Cultural Virada - que em 2018 foi transferida para a Chácara do Jóquei (na zona sul, distante do centro da cidade) e com programação que foi muito questionada pelos coletivos.

Algumas festas desistiram da burocracia dos alvarás e se mantiveram circulando de forma itinerante e independente em várias locações, até mesmo em clubes ou galpões e com estrutura logística e sonora mais profissional, como a CapsLock, a Gop Tun e a $O D D$. Estas festas mais estruturadas, com custo de 100 mil reais em média ou que contam com ajuda de patrocinadores, disponibilizam a venda de ingressos por lotes (trinta reais/ quarenta reais/cinquenta reais/ cem reais) em sites e com local revelado no dia do evento, acabando por reunir um público mais elitizado, possuindo melhor estrutura logística e sonora.

Por outro lado, há também as festas mais underground (o que se revela na gratuidade dos eventos, na ênfase política, na rusticidade da estrutura e dos equipamentos sonoros) que abriram mão do ingresso e fazem seu capital a partir do consumo do bar, contando com a contribuição de alguns frequentadores e mantendo um ethos mais agregador, democrático, horizontal que une camelôs, jovens da periferia, entre outros. Pedem ajuda 
para pagar o som, cobram ingresso a preços baixos ou deixam a entrada de graça até a 1 h da madrugada. Estas seriam a Vampire Hauss, a Caldo e a BLUM, que formam um conjunto de coletivos e festas também existente ainda hoje na cena e que analisaremos mais detalhadamente num outro artigo.

A configuração de experiências e das práticas juvenis desses coletivos de música eletrônica parecem ser pilares de zonas autônomas temporárias. Esse conceito de Hakim Bey (2001) auxilia-nos na análise dos movimentos ali gerados e os sentidos sociais e políticos num contexto de confronto com o Estado, com estratégias de ocupação de áreas de localização temporária, de economia própria, de corporalidades, de ocupação do espaço público, de ações políticas etc. A configuração de experiências em zonas autônomas temporárias (BEY, 2001) e em espaços heterotópicos (FOUCAULT, 2015) que aí se estabelecem, apontam para a dimensão espacial/territorial e sua importância para a existência e visibilidade de identidades mais plurais na cidade.

Pode-se perceber que estas festas são também atos políticos inseparáveis de suas dimensões lúdicas e afetuais, por onde circulam questões como arte urbana, inclusão, mobilidade, políticas higienistas e ocupação de espaços da cidade. Estes agentes produtores/ organizadores das festas, ao buscarem meios criativos para (re)inventarem formas de estar juntos, produzir, fazer e divulgar eventos, se apropriam da cidade, reterritorializam lugares e outorgam sentidos políticos a essas experiências urbanas. Além disso, percebemos as articulações entre política e estética (RANCIÉRE, 2009) que resultam em novas formas de sensibilidade, dissenso e na construção de formas outras de viver e de usar a cidade.

\section{CapsLock - a festa e o personagem}

Desse cenário, destacaram-se alguns personagens, personalidades e trendsetters (GARCIA CANCLINI et al., 2012), que compuseram a linha de frente; dentre eles, o artista Paulo Tessuto. Paulistano de 31 anos, aficionado pela música eletrônica dos anos 1990 desde que aos 16 anos conheceu um clube noturno. Em meados de 2006 estreou como DJ e nos anos seguintes se estabeleceu nos grandes clubes da cidade.

[...] eu tinha uns 5 ou 6 anos. Minha prima comprava aquelas revistas que vinham com $\mathrm{CD}$, coisa dos anos 90. Ela também ia para as matinês. Às vezes eu ia com a minha tia, que levava ela. Pra voltar, ela se virava rs. Agora nas pistas foi com 16. Na época eu tinha ido morar na república de jogadores de 
basquete do Clube Pinheiros e alguns rapazes iam para um tal de Lov.e ouvir um tal de Marky Marky. Na época tudo aquilo soava tão desconhecido para mim. (MUSIC DONT STOP, 2016)

Segundo relata, por conta de sua grande indignação em relação à falta de criatividade que se instituiu na cena de música eletrônica, em grande parte devido ao modelo saturado do consumo e cultura fútil e fashionista, ele se envolveu com o coletivo Voodoohop onde atuou como performer e DJ residente. A partir daí o artista articulou e estruturou novos sentidos políticos na cena, baseados em intervenções artísticas e ativismos. O cenário de crise no mundo contemporâneo, em que habita uma juventude órfã dos projetos civilizatórios da Modernidade, fez surgir e ganhar certa visibilidade figuras bastardas (AMADO; RINCON, 2015) que fazem suas políticas de sobrevivência e reexistência. Novas formas de conceber, expressar e viver o político (MOUFFE, 1993) vão se esboçando nas práticas e imaginários de grupos juvenis, em que uma noção de politicidade (ROCHA, 2012) se mostra presente. Segundo Rocha, politicidade exprimiria uma noção de politização do cotidiano não necessariamente articulada às expressões políticas tradicionais e institucionais, mas expressa em formas de estetização e corporalidades e suas implicações na vida urbana.

Com o intuito de revitalizar a cena musical e cultural eletrônica, Tessuto constituiu uma certa política de resistência espiralada e mutante em que o artista (DJ, produtor, performer, artista gráfico, agitador cultural) produz uma arte para alicerçar o universo que cria. Passa a incluir seu corpo-mídia que circula questionamentos, estilos de vida, opções políticas e identidades performatizadas e constrói um campo sonoro que mistura tecno, micro house e samplers (incluindo referências da música brasileira). A partir dos questionamentos que surgem deste universo, promove interações, engajamentos, ressoando nos espaços urbanos o diálogo entre o sujeito e a cidade contemporânea.

$\mathrm{O}$ artista construiu o anfitrião Carlos CapsLock: um mix de DJ, viral, personagem e performer. De acordo com Tessuto, o nome veio de uma brincadeira, pois Carlos é nerd e designer de teclados que convida as pessoas para seus eventos e interage com elas por meio de identidade visual e sensorial. Com o passar do tempo, o personagem foi incorporando outras estéticas: virou drag no Cine Marrocos e se vestiu de noiva na festa "Despedida De Solteiro". Possuindo uma bem formulada articulação entre o tema da festa, a cenografia, os performers, a estética/indumentária do público e o material impresso, veem-se aí elementos de estetização no sentido atribuído por 
Maffesolli (2005). Estética, segundo o autor, que não diz respeito às obras de arte institucionalizadas, mas a uma noção de criação e invenção que se dá no estar junto e no "sentir em comum" cotidiano e passa pela comunicabilidade do corpo, em suas formas de se expressar, falar, dançar, interagir, se tocar, se vestir, se despir, se montar.

\section{A festa}

A festa começou em dezembro de 2010, apresentando tecno, disco, house e eletrônico experimental. Tessuto queria transformar a cena da música eletrônica a qual, segundo ele, "era elitista, tinha pouca arte e parou no passado" e atrair um público novo. Além de construir o personagem com um conceito particular, ele desenvolveu uma comunicação inspirada na estética de telenovelas e de fanzines para dialogar com o público exclusivamente pela internet, sendo que hoje é seguido por mais de 24 mil pessoas. Mantinha essa interação durante os eventos tanto com a presença de artistas integrantes de outros coletivos (Kaka Toy, Elloanigena, Ronalda, Alex Honda etc.) como também com sugestão de dress code para os participantes, em que estética e a corporalidade ajudariam a criar formas de pertencimento e de estar juntos. Os encontros se transformavam em atos políticos e o aspecto itinerante da festa contribuiu para a circulação e fluidez do movimento.

Judith Butler, ainda na década de 1980, definia a noção de performatividade como dizendo respeito àquelas características dos enunciados linguísticos que, no momento da enunciação, já têm o poder de trazer algum fenômeno à existência. Em diálogo com J.L. Austin e J. Derrida, a autora asseverava que a performatividade é um modo de nomear um poder que possui a linguagem de produzir efeitos. Nas décadas seguintes, Butler atualizaria este conceito para incluir os atos corporais como performativos, tanto para compreender a formação do gênero, como também para compreender as manifestações dos grupos em aliança nas ruas (BUTLER, 2018). Ora, esta noção corporal definitivamente política para Butler, nos ajuda a compreender as corporalidades envolvidas nas festas que aqui analisamos.

A festa se instituiu e para poder continuar precisou se adequar à legalidade. No percurso, promoveu a inclusão com festas gratuitas (ou com ingressos a preços baixos) e o uso e ocupação de áreas abandonadas ou esquecidas na cidade. A festa também abriu espaço para as performances mais variadas de grupos LGBTQI+ e com uma 
ambientação de iluminação e projeções atraiu uma gama diversificada de pessoas que procurava se expressar e se (re)conhecer. Tessuto sintetiza a festa "como refúgio dos oprimidos". Percebemos aqui desdobramentos políticos e irrupções a favor das pautas comuns que resultam numa composição de grupos que, dentro da experiência urbana, reúnem bastardos, periféricos, nômades etc. Com Rancière (2009), podemos ver nesse acontecimento das festas um jogo entre política e estética que resulta em novos modos de sentir, afetar-se e ser afetado.

O movimento se espalhou por várias partes do país. Cidades como Belo Horizonte, Rio de Janeiro, Curitiba, Salvador, Porto Alegre possuem hoje festas com esse formato, sendo que Tessuto hoje é DJ agenciado e circula pelo Brasil e pelo mundo. Em São Paulo, além de um público único e específico como no caso da CapsLock, existem várias festas de música eletrônica de pista acontecendo no mesmo dia, em quase todos os finais de semana, o que reflete o sucesso desse modelo.

No entanto, para entendermos o caminho que a festa percorreu, procuramos elementos para uma análise que nos permita entender como se movimentaram esses coletivos nesses anos, bem como alguns acontecimentos que os atravessaram. Por meio da fanpage no Facebook, analisamos os eventos realizados entre junho de 2012 e setembro de 2018, num total de 76, que mistura festas, afters, participações extra festa e outros eventos culturais que CapsLock organizou ou participou.

De imediato, chamou-nos atenção as temáticas das festas (das quais falaremos abaixo) e, principalmente, o discurso do personagem expresso em sua comunicação. A escrita só contém letras em caixa alta, quase sem pontuação, flexionando e reinventando a língua, agregando novos sentidos às palavras, criando novos conceitos (como ravetalização, por exemplo), e muitas vezes fazendo desenhos com caracteres.

No primeiro evento analisado em 2012, Carlos CapsLock funda seu partido, o PCC - Partido Carlos CapsLock, em ironia ao horário eleitoral gratuito daquele ano. Dos 8 eventos de 2012, notamos que parte dos temas fazem associação direta às questões políticas - como a construção da usina de Belo Monte e as eleições municipais. As festas ocorreram na Trackers - espaço alternativo localizado no centro da cidade. Ocorreram também festas ao ar livre, nos eventos da prefeitura ou em datas programadas. Lançou o Rivotrio, trio elétrico de música eletrônica que circula pela cidade. CapsLock anuncia a morte do personagem e demonstra um desconforto com as brigas na cena que começam a acontecer: a "GUERRA DO UNDERGROUND". 
11/5 UFC - ULTIMATE FIGHTING CAPSLOCK

[[[[[ENTRADA SOMENTE COM NOME NA LISTA E PROTETOR BUCAL]]]]]

UM NOVO CONCEITO DE LUTA...ARTISTAS, PERFORMERS, DJS, PRODUTORES...AGUARDEM O ANUNCIO DAS LUTAS! COMPRE SUA CAMISETA, O SEU BONE E VENHA PARA O UFC PORQUE SO SE FALA EM OUTRA COISA. VOCE VAI DESACREDITAR!

Notam-se também tentativas de interação com o público: pedindo para subir ao palco, promovendo festivais de vídeo ou concursos de artes de flyer, conscientizando sobre o lixo gerado nos espaços e convidando outros coletivos para fortalecer a ação.

Nos 12 eventos de 2013, as questões políticas permaneceram de forma subentendida, mas os temas giraram em torno de uma crítica da própria cena, com a "Festa Junina Glam + Rodeios de Merda" ou "República do Camarote: House Ostentação". A "Festa da Firma" parecia ironizar os coletivos, as chamadas panelas que se formam nestes circuitos. Nesse ano, destacamos a festa no "Anhangabaú da Felicidade" e a participação em eventos como "Pop Porn"; Carlos também foi pra "Berlim do Pará" e desafiou o público no quiz "porque eu quis".

CONCURSO CULTURAL CARLOS CAPSLOCK PORQUE EU QUIZ?? CARLOS CAPSLOCK PORQUE EU QUIZ, RESPONDA A PERGUNTA QUE NAO QUER CALAR. POSTE UM VIDEO PARA A GENTE CONTANDO O QUE VOCE FEZ E PORQUE...PORQUE VC QUIS! OU ENTAO POSTE UM MEME DO CAPITAO CAPSLOCK EXCLUSIVO CRIADO ESPECIALMENTE PARA A CAPSLOCK PORQUE EU QUIS. COMO? TODAS AS PESSOAS QUE FIZEREM VIDEOS/MEMES E POSTAREM NO MURAL DO EVENTO GANHARAO ADESIVO DO CAPSLOCK, SABE PORQUE? PQ EU QUIS!!!!

O ano de 2014 parece ter sido o auge das festas: foram eventos quinzenais, 20 no total e um aumento do público. Neste ano, o crescimento dos eventos organizados pela Prefeitura foi notório: SP na Rua, Virada Cultural e MCI, aludindo a uma certa sinergia entre as ações que vinham sendo levadas a cabo pelos coletivos e as políticas públicas estatais. Ocorreu também outra edição do Rivotrio circulando pelas ruas e uma tarde no entorno do Parque do Ibirapuera. Comemorando 3 anos da festa, no decorrer do ano frisou temas políticos: deu apoio aos rolezinhos que aconteciam naquele momento, demonstrou 
preocupação com a crise e o racionamento de água na cidade, atentou para o sucesso do Papa Francisco em visita ao Brasil e para mudanças nas políticas ligadas ao trabalho.

Teve como ápice a participação na ocupação do Cine Marrocos, na qual destinou $50 \%$ da renda para a ocupação. Carlos anunciou sua mudança para Berlim e a festa ainda abriu oportunidades para novos DJs enviarem seus trabalhos; participou ainda de duas exposições, uma na 'Galeria de Arte Carlos CapsLock'. Observamos também uma interação com o coletivo Mamba Negra (festa que já aludimos).

14/11 RACIONAMENTO: A FESTA - CARLOS CAPSLOCK CONVIDA
PRO FIM
CONFORME ANUNCIADO
FESTA NO

No ano de 2015, apesar dos eventos da Prefeitura terem se mantido, os alvarás começaram a se tornar cada vez mais difíceis de serem obtidos. Foram 14 festas naquele ano, que contaram com a participação de diversos artistas de Berlim e em que, pela terceira vez, acontecia o Rivotrio. Carlos esteve em Berlim por alguns meses, participando e oferecendo workshops de formação com temas relacionados à produção musical, biohacking e serigrafia. As festas abordaram temas como o Golpe de Estado contra Dilma Rousseff entre outras pautas políticas institucionais. CapsLock anuncia ainda em 2015 a ida a Berlim para fazer cirurgia de mudança de sexo e faz uma festa com os DJs montados, exatamente quando se inicia a montação do personagem. Lança ainda o selo musical do coletivo, chamado MEMNTGN.

Com 6 anos, a festa já estava bem estabelecida, contando com atrações internacionais. No ano de 2016 ocorreram 12 festas, algumas delas com exposições, workshops e oficinas. Permaneceu participando dos eventos da Prefeitura e com a nova edição do Rivotrio. As pautas políticas fervilharam, apoiando as informações divulgadas pelo Wikileaks, ironizando a Operação Lava-Jato, a venda do pré-sal, a PEC 171, o "MISS TÉRIO DA CULTURA'. 
Em 2017, as festas começam a se pulverizar, o que reduziu o público e o número de edições. Foi quando começaram os patrocínios e o início de uma fase mais padronizada. Trazemos como destaque o CCCC - Centro Cultural Carlos CapsLock, numa antiga fábrica de azeite alugada na Freguesia do Ó, zona norte de São Paulo. Dos 14 eventos realizados nesse espaço, 3 foram edições de uma feira orgânica, com workshops, exposições e filmes. Lá funcionava a ÇÇÇÇ - Çala Çatélite Çarlos Çapslock, de live streaming. Entre festas na rua ou em galpões próximos ao centro, CapsLock lutou pela cultura: "LUTAREMOS PELA NOSSA CULTURA QUE VEM POUCO A POUCO SENDO MINADA DE NOSSAS VIDRAS"; pede novas eleições com D-JÁ - DIRETAS JÁ. Depois de falar sobre revolta, revolução, propõe começar uma nova cena, zerando modas, já com famosos nomes nacionais e internacionais nos lines.

29/7 Carlos CapsLockChammaRave (S)olucao In DustrialPos Verdade NAO DEIXEMOS QUE A REVOLUÇAO SEJA COMO A JUSTIÇA QUE TARDA, TARDA E TARDA PRA FALHAR! A DANÇA ASSIM COMO A REUNIAO FEZ FAZ E SEMPRE FARA PARTE DE QUALQUER REVOLUÇAO, SEJA ELA NDUSTRIAL, A FRANCESA OU EMPANADA. NAO DEIXEMOS QUE A POS VERDADE DAS LISTAS VIBORA DEVOREM NOSSOS PAÇOS DE GIGANTE ATORDOADO. DE VOLTA A FABRIKA NOSSA NOVA CASA! VEM QUE TEM TREM! CARLOS CAPSLOCK CHAMMA RAVE (S)OLUÇAO IN DUSTRIAL! OPERAIOS HA VANTE! NOS SOMOS A MASSA E A MASSA TA MASSA PRA CARAI!

No último ano da nossa análise, 2018, observa-se um retorno à house music e um olhar para o seu legado: ressaltando a DJ culture e a cultura rave, buscando se conectar com as ideias originárias da festa, numa invocação de seu legado como atuante da cena desde os anos 1990, evidenciando fatos históricos e culturais daquela década e construindo uma certa tradição seletiva (WILLIAMS, 1979). Aumentam as atrações internacionais e ocorre a festa que encerra nossa análise, da qual participamos presencialmente, na comemoração de "7 anos e meio".

07/9 Carlos CapsLock Entra Numas de Anos 90's

OS ANOS 90 COMEÇÇARAM COM INSTABILIDADE, COM O CONFISCO DAS POUPANÇAS CLUBBERS MAIS AI WEIO O PLANO IRREAL QUE DEU UMA LUZ NO FIM DA PISTA. O PLANO REALL 
EH LANÇÇADO EM 1994. A CULTURA BRASILEIRA TORNOUSE MAIS VALORIZADA, COM A RESSURREIÇÇAO DO CINEMA E A BOA RECEPÇÇAO DE MUSICOS BRASILEIROS NO EXTERIOR POPULARIZAÇÇAO DO WINDOWS, CELULARES MOVEIS, PAGERS, OVELHADOLLY, MORTEDOCAZUZA, RENATORUSSO, MOVIMENTO DA MUSICA ELETRONICA, TEMOR DO BUG DO MILENIO, SISTEMA LINUX, DVD, PLAYSTATION, SUPER NAO ENTENDO E MEGA DRIVE. HUBBLE, SONDA GALILEU, REUNIFICAÇÇAO DA ALEMANHA, CAZUZA E RENATO RUSSO. UFA! EH COISA PAH MAIS DE METROW E PRA CELEBRAR ESSA DECADA QUE MARCOU A VIDA DE MUITAS CLUBBERS E CLUBERS, \#CARLOSCAPSLOCK ENTRA NUMA DE ANOS 90

\section{Considerações Finais}

A pesquisa que realizamos (da qual este artigo é fruto) tem como objetivo central a realização de uma cartografia da cena de coletivos juvenis de festa de música eletrônica de pista, que surgiram em São Paulo a partir de 2010. Eles se proliferaram nos anos decorrentes, tiveram um crescimento expressivo em 2013/2014 e se mantêm atuantes, apesar de muitas mudanças, até os dias de hoje. Seus (des)caminhos, suas dinâmicas, controvérsias, bifurcações, parecem apontar para sentidos difusos que esta cena vem tomando na atualidade. Por um lado, algumas festas vêm se adaptando a uma lógica mais próxima do mainstream já conhecido na cena eletrônica, ao cobrar preços altos, construir uma estrutura de evento cara e sofisticada (seja nas instalações, seja no equipamento sonoro) e atrair como frequentadores parcelas da elite. De outro modo, algumas festas já deixaram de existir, seja por convicções ideológicas, seja por não terem conseguido driblar as regras e o controle cada vez mais ostensivo das instituições (prefeitura, polícia, mercado). Por outro lado, há também as festas que seguem resistindo e reinventando-se, cada vez mais engajadas e expressando seus sentidos políticos de inclusão, de mobilidade urbana, de uso e ocupação da cidade.

As transformações pelas quais a festa passou refletiram também no frontman mutante Carlos CapsLock e na carreira do DJ Paulo Tessuto que deslanchou e se legitimou. Tessuto diz que nem imaginava aonde ia chegar quando iniciou as primeiras festas na rua em 2010. Os frequentadores habituais foram unânimes em reconhecer que a festa "está muito diferente agora". Mas é nítido o esforço de CapsLock para se manter inovador buscando elementos de crítica social, política e estética em toda a duração de mais de 
7 anos do evento. A festa começou dentro de outra festa (Voodoohop), estabeleceu-se fora desta e se transformou num fenômeno replicado por diversos coletivos. A partir daí a diluição parece ter sido inevitável, somada ao cenário político, social, econômico e cultural em que vivemos nos últimos anos de crise financeira e endurecimento político. As saídas foram várias: ora se rendendo aos patrocinadores para viabilizar a festa, ora tendo um lugar próprio que pode ser retomado no futuro. As práticas foram se adaptando para que a ideia, mesmo que já longeva, continuasse.

Analisar o personagem e a festa CapsLock nos parece uma forma de acompanhar diferentes momentos desta cena musical nesta década, desde seus primórdios de presença nas ruas, passando pelo momento de proliferação das muitas festas e coletivos, alcançando um certo auge, e seu momento atual de indefinição e abertura de novos e múltiplos caminhos bifurcados e controversos. O encaminhamento tomado pela CapsLock, se não é um modelo necessariamente seguido por todos os coletivos e festas da cidade, aponta para ambiguidades e contradições presentes nas cenas musicais, urbanas e juvenis, como já discutimos em outros artigos (PEREIRA; BORELLI, 2015; PEREIRA, 2017; PEREIRA; GHEIRART, 2018). Os caminhos de internacionalização e até certa elitização que acompanham esta festa revelam aspectos para os quais podem se direcionar as cenas musicais (como esta que se baseou nas ruas), de um certo esvaziamento de conteúdos mais explicitamente políticos, underground e de enfrentamento, acompanhado de processos de profissionalização crescente. No entanto, isso não faz com que estejam excluídas formas estéticas, corporais e sonoras que se querem questionadoras e até disruptivas. Estas contradições parecem ser a riqueza da cena e da festa em questão.

Nesse cenário, avistamos esses jovens que herdaram efeitos das crises econômicas e sociais basilares do século XXI, no qual a precarização parece ser a regra, bem como a ausência do Estado na promoção de bem-estar social e de cultura. Aliadas às novas formas de visibilidade e agenciamentos juvenis de grupos minoritários como negros, trans, mulheres, grupos LGBTQI+, periféricos, vão se esboçando novas formas de inventar e viver a política, algo que buscamos aqui compreender investigando modos de articulações e associações juvenis nos coletivos que promovem festas de música eletrônica de pista em São Paulo.

Temosbuscado vestígios de ações, derealizações, desdobramentose, principalmente, indícios de novas maneiras de pensar e experimentar o político (MOUFFE, 1993). Entendemos o estar juntos e ocupar a cidade como possibilidade de novas dimensões performativas da política (BUTLER, 2018) com outras configurações de vida, resistências 
e (re)existências em formas de brechas e fissuras nos sistemas políticos e econômicos, no Estado, nas lógicas do funcionamento da cultura e do entretenimento na cidade de São Paulo. Uma (re)existência que se perfaz usando a música, a dança, a corporalidade, a performatividade em novas maneiras de ser e estar na cidade. Estes jovens ativistas musicais/culturais/urbanos resistem à velocidade dos fluxos metropolitanos, reconfiguram o tempo num processo de prolongamento, lutam contra a agilidade da indústria da cultura e se aproveitam da velocidade das redes.

Corpos que se montam, se vestem, se despem, se encontram, se articulam, se vinculam, performatizam identidades e ocupam as ruas e outros territórios sublinham o viés político destas festas numa dimensão performativa da própria política, uma vez que está ancorada em ação e engajamento de afetos e corpos em formas de estar e fazer coisas juntos.

\section{Referências}

AMADO, Adriana ; RINCÓN, Omar. La reinvención de los discursos o cómo entender a los bárbaros del siglo XXI. In: AMADO, Adriana ; RINCÓN, Omar. (Eds.). La comunicación en mutación: remix de discursos. Bogotá: Friedrich Ebert Stiftung, 2015.

BEY, Hakim. TAZ - Zona Autônoma Temporária. São Paulo: Ed. Konrad, 2001 (Versão digital - Coletivo Sabotagem).

BUTLER, Judith. Corpos em aliança e a política das ruas: notas para uma teoria performativa de assembleia. Rio de Janeiro: Civilização Brasileira, 2018.

FERNANDES, Cintia; HERSCHMANN, Micael. Usos da cartografia nos estudos de comunicação e música. Fronteiras - Estudos Midiáticos. v.17, n.3, 2015. p.290-301.

FOUCAULT, Michel. Outros espaços - Heterotopia. In: FOUCAULT, Michel. Ditos e escritos. vol. III - estética: literatura e pintura, música e cinema. Rio de Janeiro: Forense Universitária, 2015. p. 428-438.

GARCIA CANCLINI, Nestor et al. Jóvenes, culturas urbanas y redes digitales. Madri: Telefonica, 2012. 
HAESBAERT, Rogerio. Territórios alternativos. São Paulo/Rio de Janeiro: Contexto/EdUFF, 2002.

LATOUR, Bruno. Reagregando o social - uma introdução à Teoria Ator-Rede. Salvador: Edufba, 2012.

MAFFESOLI, Michel. Ética da estética. In: MAFFESOLI, Michel. O mistério da conjunção. Porto Alegre: Sulinas, 2005.

MASSEY, Doreen. Filosofia y politica de la espacialidade - algunas consideraciones. In: ARFUCH, L. (org.) Pensar este tiempo: espacios, afectos, pertenencias. Buenos Aires: Paidós, 2005 .

MOUFFE, Chantal. El retorno de lo político: Comunidad, ciudadanía, pluralismo, democracia radical. Barcelona: Paidós, 1993.

MUSIC DONT STOP. De jogador de basquete a DJ drag, Paulo Tessuto chegou "lounge" na noite de SP com sua festa Carlos Capslock. (Por Claudia Assef). 26 de fevereiro de 2016. Disponível em https://musicnonstop.uol.com.br/de-jogador-de-basquete-a-dj-drag-paulo-tessuto-comemora5-anos-de-capslock-neste-sabado/ Acesso em 10 jul. 2019.

PEREIRA, Simone Luci. Circuito de festas de música "alternativa" na área central de São Paulo: cidade, corporalidades, juventude. FAMECOS - mídia, cultura, tecnologia. v.24, n.2, 2017.

PEREIRA, Simone Luci e GHEIRART, Oziel. Coletivos de música eletrônica em São Paulo: usos da cidade, culturas juvenis e sentidos políticos. E-compós. v.21, n.3. 2018.

PEREIRA, Simone Luci e BORELLI, Silvia Helena. Música alternativa na Vila Madalena: práticas musicais juvenis na cidade. Fronteiras - Estudos Midiáticos. v. 17, n. 3, 2015.

RANCIÉRE, Jacques. A partilha do sensível. São Paulo: Ed. 34, 2009.

REIA, Jhessica; HERSCHMANN, Micael; FERNANDES, Cintia. Entre regulações e táticas: músicas nas ruas da cidade do Rio de Janeiro. Famecos - mídia, cultura, tecnologia. Porto Alegre, v. 25, n. 3, p. 1-23, set-dez/2018.

ROCHA, Rose de Melo. Corpos significantes na metrópole discursiva: ensaio sobre fetichismo visual e ativismo juvenil. Significação - Revista de cultura audiovisual. Universidade de São Paulo (USP) v.39, n.37, p.126-146, 2012. 
STRAW, Will. Cenas culturais e as consequências imprevistas das políticas públicas. In: JANOTTI JR, J.; SÁ, S.P. (orgs.) Cenas musicais. Guararema/SP: Anadarco, 2013.

WILLIAMS, Raymond. Marxismo e Literatura. Rio de Janeiro: Zahar, 1979.

${ }^{1}$ Pesquisadora do CNPq (PQ-2). Mestre em História Social (1998) e Doutora em Ciências Sociais - Antropologia (2004) pela Pontifícia Universidade Católica de São Paulo. Realizou três Pós-Doutorados: dois no Brasil, a)no PPG Música da UNIRIO (bolsista PosDoc Sênior FAPERJ - 2012-2013), junto ao GP Música Urbana no Brasil, e outro b) no PPG Comunicação da UFRJ, junto ao NEPCOM (2016-2017); e ainda um Posdoc internacional, no Progranma de Investigación Posdoctoral en Ciencias Sociales, Niñez y Juventud (Red CLACSO de Posgrados e Red INJU (2014-2016). Participa da rede internacional de investigação do Grupo de Trabalho CLACSO Juventudes y Infâncias en América Latina. Professora Titular do PPG Comunicação e Cultura Midiática (Mestrado e Doutorado) da Universidade Paulista - UNIP. Coordenadora do Grupo de Pesquisa "Comunicação e Culturas Urbanas" da INTERCOM (2017-2020). Coordenadora do Grupo de Pesquisa URBESOM (Culturas Urbanas, Música e Comunicação). Vice-presidente da IASPM-LA (Associasión internacional para el estudio de la musica popular Rama Latinoamericana) (2018-2020). Pesquisa e atua na interface dos campos da Comunicação, Música e Antropologia, com ênfase nos estudos sobre práticas musicais-midiáticas, culturas urbanas, cidades e juventudes; migrações/diásporas, identidades e interações sociais vinculadas às práticas musicais-midiáticas; memória, escuta e música midiática. Tem participado de eventos científicos no Brasil e no exterior e publicado vários trabalhos em anais de eventos, periódicos e livros coletâneas de artigos. Atua como parecerista em periódicos nacionais e internacionais e agências de fomento. E-mail: simonelp@uol.com.br.

${ }^{2}$ Publicitário; Artista e músico. Especialista em Gestão de Processos Comunicacionais; Mestre em Comunicação e Práticas do Consumo; e Doutor em Ciências Sociais. É integrante dos grupos de pesquisa "Juvenália: Culturas juvenis: comunicação, imagem, política e consumo" e UrbeSom - Culturas urbanas, música e comunicação. E-mail: gheirart@yahoo.com. 